\title{
UTILIZATION OF POLYSPECIFIC ANTISERUM FOR SPECIFIC RADIOIMMUNOASSAYS: RADIOIMMUNOASSAYS FOR RAT FETUIN AND BIKUNIN WERE DEVELOPED BY USING ANTISERUM AGAINST TOTAL RAT SERUM PROTEINS
}

Key words: Radioimmunoassay, polyspecific antiserum, rat fetuin, rat bikunin

Edwin Fink, Gudrun Godec, Marianne Arnhold and Peter Nawratil

Department of Clinical Chemistry and Clinical Biochemistry, Hospital of Surgery, University of Munich, Nussbaumstr. 20, D-8000 Munich 2, Germany

\section{ABSTRACT}

Polyspecific antiserum against total rat serum proteins was used to develop specific and sensitive radioimmunoassays for fetuin and bikunin, two minor protein components of rat plasma. The radioimmunoassays proved to be highly useful to trace bikunin and fetuin in the course of developing isolation procedures, since neither specific functional assays nor monospecific antisera were available. The two examples demonstrate that, in general, it will be possible to 
develop a specific and sensitive radioimmunoassay with antiserum raised against a crude antigen preparation, such as a body fluid or a tissue extract, provided that a minute amount of pure antigen is available for preparing the radioiodinated antigen.

\section{INTRODUCTION}

Radioimmunoassays have been widely used for the specific determination of many protein and other antigens. They are based on the competition of radioactively labeled and unlabeled antigen for binding to a specific antibody ${ }^{1}$. The presence of an antigen in a sample is recognized by the partial inhibition of the binding of radioactively labeled antigen to the antibody. Generally one uses monospecific antibodies in radioimmunoassays, but from a theoretical point of view this is unnecessary, since other antibodies present in the incubation mixture do not influence the reaction between the antigen to be determined and its cognate antibody. Therefore, antiserum against a crude antigen may be employed in radioimmunoassays provided that pure antigen is used as a tracer.

We would like to direct attention to this special aspect of radioimmunoassays of which researchers experienced in immunoassay techniques will be aware, but which is, nevertheless, often overlooked. Making use of this aspect can be of considerable practical value for example when a specific assay for a protein is needed, but the amount of available antigen is too low, or time too short for antiserum production: a radioimmunoassay may be set up using an antiserum raised against a crude preparation of the protein or even against a raw extract of the tissue which contains the protein. Here we report radioimmunoassays for the determination of two minor components of rat plasma, fetuin ${ }^{2}$ and bikunin ${ }^{3}$, by using purified proteins for tracer preparation and as stan- 
dards, and a commercially available antiserum against whole rat serum protein. Both assays were used for developing and optimizing the isolation procedures.

\section{MATERIALS AND METHODS}

Na125I: IMS30, Amersham Buchler, Braunschweig, Germany; Tween 20 (37470), polyethylene glycol 6000 (33137), thimerosal (77018), bovine serum albumin (11930), rabbit gamma-globulin (22540): Serva, Heidelberg, Germany; PD-10 column: Pharmacia; rabbit anti-rat serum: Z 178, Dakopats, Denmark; precipitating antiserum: donkey anti-rabbit immunoglobulin $G$ antiserum, APPT1, IDS, Tyne \& Wear, England; chloramine T (2426) and all other reagents (analytical grade): E. Merck, Darmstadt, Germany; RIA tubes (73.1055): Sarstedt, Nümbrecht, Germany; Gamma-counter: Hydragamma 16, Zinsser, Frankfurt, Germany.

Rat bikunin ${ }^{4}$ and fetuin ${ }^{2}$, from rat plasma were available in amounts of about $200 \mu \mathrm{g}$. Purity of the proteins was verified by N-terminal amino acid sequencing using a gas phase sequencer (Applied Biosystems, Model 477A) connected to an on-line HPLC 120A system for identification of the phenylthiohydantoin derivatives. Protein concentrations of antigen stock solutions were determined by amino acid analysis.

Buffers. Buffer A: $15 \mathrm{mM} \mathrm{NaH}{ }_{2} \mathrm{PO}_{4}, 0.15 \mathrm{M} \mathrm{NaCl}$, pH 7.4; buffer B: buffer $\mathrm{A}$ containing in addition $200 \mathrm{mg}$ thimerosal $/ 1,2.0 \mathrm{~g}$ bovine serum albumin/1, $0.01 \mathrm{M}$ EDTA; buffer C: same as buffer B but containing $40 \mathrm{~g}$ bovine serum albumin/l; buffer D: buffer B containing in addition $60 \mathrm{~g}$ polyethylene glycol 6000/1.

Iodination. All reagents were dissolved in buffer A. $10 \mu \mathrm{l}$ protein solution (containing $2 \mu \mathrm{g}$ rat fetuin or $1.5 \mu \mathrm{g}$ rat bikunin), $10 \mu \mathrm{l}(0.33 \mathrm{mCI}=12.3$ 
MBq) Na ${ }^{125} \mathrm{I}$ and $10 \mu \mathrm{l}(30 \mu \mathrm{g})$ chloramine $\mathrm{T}$ were mixed in a glass vial with conically shaped bottom. After 5-10 s $20 \mu 1$ of a solution of sodiumdisulfite (3 $\mathrm{mg} / \mathrm{ml}$ ) was added. The mixture was immediately transferred to a PD-10 column which had been pretreated with $3 \mathrm{ml}$ buffer $\mathrm{C}$ and equilibrated with $30 \mathrm{ml}$ of buffer $\mathrm{A}$. The vial was rinsed once with $50 \mu \mathrm{l}$ of a potassium iodide solution, 10 $\mathrm{g} / \mathrm{l}$. The column was eluted with buffer $\mathrm{A}$ and $0.5 \mathrm{ml}$ fractions were collected into polypropylene tubes containing $50 \mu \mathrm{l}$ buffer $\mathrm{C}$. The $2-3$ fractions with the highest radioactivity of the first radioactivity peak were pooled and diluted with buffer B to approximately 500,000 counts $/ \mathrm{min} / \mathrm{ml}$ and rabbit gamma-globulin, $70 \mathrm{mg} / \mathrm{l}$, was added. The calculated specific radioactivities were $14-20 \mu \mathrm{Ci} / \mu \mathrm{g}$ for fetuin and $60-110 \mu \mathrm{Ci} / \mu \mathrm{g}$ for bikunin.

Titration Curves. Appropriate dilutions of the antiserum to rat serum were determined by setting up titration curves. $100 \mu \mathrm{l}$ buffer B, $50 \mu \mathrm{l}$ anti-rat serum (dilutions from 1:400 to 1:64,000 in buffer $\mathrm{C}$ ), $50 \mu$ l of labeled antigen $(25,000$ counts $/ \mathrm{min}$ ) were mixed and incubated for 14-18 $\mathrm{h}$ at room temperature. Then $50 \mu \mathrm{l}$ of precipitating antiserum (dilution 1:32 in buffer $\mathrm{C}$, optimized for this system following the manufacturer's instruction) and $250 \mu 1$ of buffer D were added. The tubes were centrifuged immediately for $15 \mathrm{~min}$ at about $4000 \mathrm{~g}$. The supernatant was aspirated, the pellet washed once by adding $250 \mu 1$ buffer D, centrifugation and aspiration of the supernatant. Then the radioactivity of the precipitate was measured.

Radioimmunoassay procedure. $50 \mu \mathrm{l}$ each of buffer B, sample (unknown or standard, 0.4-200 $\mu \mathrm{g} / \mathrm{l}$, in buffer B), labeled antigen, and diluted rabbit antiserum to rat serum were mixed in RIA tubes and incubated for 16-24 $\mathrm{h}$ at room temperature. Precipitation by the second antibody and counting was performed as described above. The results were evaluated on-line by the spline approximation method using the program RIALOG II (Zinsser, Frankfurt, Germany). 


\section{RESULTS AND DISCUSSION}

Recently it was reported that rat plasma contained an inhibitor to the insulin receptor tyrosine kinase ${ }^{5}$ which turned out to be identical with rat fetuin ${ }^{2,6}$

In order to perform studies on the function of fetuin we set out to isolate it from rat plasma, but neither an assay procedure nor a specific antibody were accessible to us. Therefore, since a small amount of fetuin was available, we investigated whether a commercial antiserum against whole rat serum could be utilized to develop a radioimmunoassay for rat fetuin. Later, the suitability of using such a polyspecific antiserum in radioimmunoassays was further corroborated by setting up a radioimmunoassay for rat bikunin employing the same antiserum as for the fetuin assay (bikunin is the inhibitorily active subunit of inter- $\alpha$-trypsin inhibitor $)^{3}$.

The antigens were radioiodinated by the chloramine $T$ method $(7)$ which is generally applicable for iodination of proteins containing tyrosine and/or histidine residues, is easy to perform and requires only minute quantities of protein; in our experiments we used 1-2 $\mu \mathrm{g}$ for one iodination.

Fig. 1 shows titration curves for radioiodinated rat fetuin and rat bikunin. The maximum percentage of radioactive antigen bound by the antibody varied for different iodinations, it was about 15-38 \% for fetuin and 19-51 \% for bikunin (five iodinations each). This binding is relatively low and may be due to alterations of molecular structures during iodination. Nevertheless, all of these tracer preparations were used in the radioimmunoassays, some of them for up to three months. For the radioimmunoassays, antiserum dilutions were chosen from the titration curves which caused a binding of radioactivity of about two thirds of maximum binding. As the radioimmunoassays were to be used mainly during developing isolation procedures of the two proteins and not for routine quantifi- 


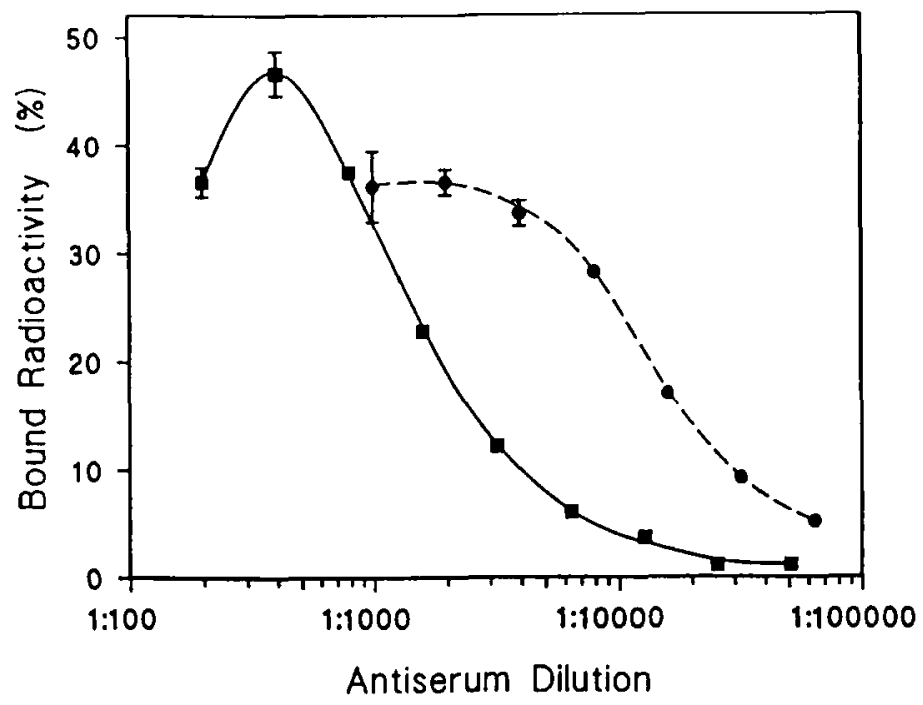

FIG. 1. Titration curves of rat bikunin and fetuin. Dilutions of antiserum to rat serum protein were incubated with radioiodinated rat bikunin $(-)$ and fetuin (--), respectively. Percentage of bound radioactivity was calculated by 100(B$\mathrm{N} / \mathrm{T}-\mathrm{N}$; $\mathrm{B}$ : bound radioactivity, $\mathrm{T}$ : total radioactivity, $\mathrm{N}$ : bound radioactivity in the absence of antiserum.

cation of the antigens, no effort was put into validating the assays in respect of, for example recovery of added antigen or parallelity of dose-response curves of serial dilutions of rat plasma and standard curves.

The calibration curves of Fig. 2 show that rat bikunin and fetuin can be reliably determined in the ranges of 0.7-70 $\mu \mathrm{g} / 1$ and 3.0-150 $\mu \mathrm{g} / 1$ (corresponding to $10-90 \%$ of bound radioactivity). Both radioimmunoassays were utilized for developing procedures for the isolation of the two proteins from rat plasma (publications in preparation).

The concentrations in several pools of rat plasma as determined by the radioimmunoassays were for bikunin $40-80 \mathrm{mg} / 1$ and for fetuin $135-320 \mathrm{mg} / 1$. 


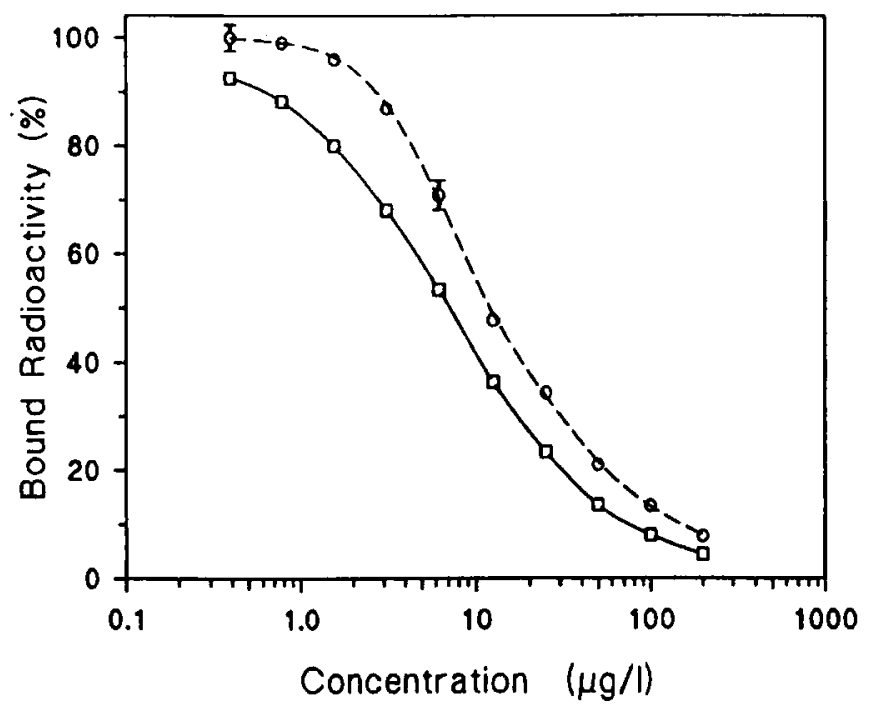

FIG. 2. Standard curves of the radioimmunoassays for rat bikunin and fetuin. Increasing amounts of bikunin (-) and fetuin (--) were incubated in the presence of a constant amount of labeled antigen with a constant dilution of antiserum to rat serum protein. Percentage of bound radioactivity was calculated by $100\left(B-N / B_{0}-N\right)$; $B$ : bound radioactivity, $B_{0}$ : bound radioactivity in the absence of unlabeled antigen, $\mathrm{N}$ : bound radioactivity in the absence of antiserum.

These low concentrations, corresponding to about $0.06-0.11 \%$ and $0.2-0.5 \%$ of total rat serum proteins to which the antiserum had been raised, demonstrate convincingly that immunization may be performed with extremely crude antigen preparations containing only traces of the particular antigen and, still, antisera can be obtained highly suitable for setting up sensitive radioimmunoassays. Generally, it will be sufficient to use all of the protein of biological fluids or tissue extracts for immunization, or, if the fraction of the antigen is too low, a partially purified protein preparation.

Polyspecific antisera must be used with caution because the requirement for monospecificity in the radioimmunoassay cannot be guaranteed. For poly- 
specific antisera, the absence of crossreacting proteins in samples which have to be analysed, and which could compete in the radioimmunoassay, cannot be verified by techniques like Ouchterlony or immunoblot analysis, as it is possible for monospecific antiserum. The use of antisera raised against crude antigens will be of high value mainly in cases where monospecific or monoclonal antibodies are not available.

In comparison to enzyme immunoassays, the radioimmunoassay is superior because of the fact that extremely low quantities of labeled antigen can be prepared easily and purified without any thorough optimization of the labeling procedure.

\section{REFERENCES}

1. Yalow, R.S. (1980) Annu. Rev. Biophys. Bioeng. 9, 327-345.

2. Rauth, G., Pöschke, O., Fink, E., Eulitz, M., Tippmer, S., Kellerer, M., Häring, H.-U., Nawratil, P., Haasemann, M., Jahnen-Dechent, W., and Müller-Esterl, W. (1992) Eur. J. Biochem. 204, 523-529.

3. Gebhard, W., Hochstrasser, K., Fritz, H., Enghild, J.J., Pizzo, S.V. and Salvesen, G. (1990) Biol. Chem. Hoppe-Seyler 371 Suppl., 13-22.

4. Albrecht, G.J., Hochstrasser, K. and Schönberger, O. (1983) HoppeSeyler's Z. Physiol. Chem. 364, 1697-1702.

5. Auberger, P., Falquerho, L., Contreres, J.O., Pages, G., Le Cam, G., Rossi, B., and Le Cam, A. (1989) Cell 58, 631-640.

6. Haasemann, M., Nawratil, P. and Müller-Esterl, W. (1991) Biochem. J. 274, 899-902.

7. Greenwood, F.C., Hunter, W.L. and Glover, J.J. (1963) Biochem. J. 89, 114-123. 